\title{
N-telopeptide to Creatinine Ratio Measurement
}

National Cancer Institute

\section{Source}

National Cancer Institute. N-telopeptide to Creatinine Ratio Measurement. NCI

Thesaurus. Code C120645.

The determination of the ratio of $\mathrm{N}$-telopeptide compared to creatinine present in a sample. The measurement may be expressed as a ratio or percentage. 